\title{
ANALISIS STRUKTUR DAN KAIDAH KEBAHASAAN TEKS EKSPLANASI PADA SURAT KABAR PIKIRAN RAKYAT SEBAGAI ALTERNATIF BAHAN AJAR KELAS XI SMA
}

\author{
lit Lita Apriani ${ }^{1}$, Dindin Zaenal Muhyi ${ }^{2}$, Adi Rustandi ${ }^{3}$ \\ 1,2,3Pendidikan Bahasa dan Sastra Indonesia FKIP Universitas Pasundan \\ 1iitlitaapriani@gmail.com, 2Dindin.mzm@unpas.ac.id, ${ }^{3}$ adirustandi@unpas.ac.id
}

\begin{abstract}
This research was conducted to give solutions to problems in learning, one of the problem is the difficulty of teachers in choosing or determining the right teaching materials for students. Besides that the difficulty of the students to distinguish explanatory text from other texts be a problem too. This research hopefully can give a solution for choosing the right variative teaching materials that accordance with explanatory text learning in high school. The purpose of this research is to analyze the structure and linguistic rules of the explanatory text contained in the pikiran rakyat's newspaper as an alternative to the selection of explanatory text teaching materials in the 11 grade of high school. The methode which was used in this research was qualitative descriptive. The data source used in this research was 10 text explanation from pikiran rakyat's newspaper. The research data obtained in the form of results of structural analaysis and ruleness of language of explanation's texts as follows. First, the structure of explanation's text is title, general statement, order of processes of phenomena, and closing statement. Second, the rules of the explanations's text includes temporal conjunctions and conjunction of causality. Third, explanaton's text teaching materials based on the results of the analysis that have been carried out and can be used in learning text material explanation in 11 grade of high school.
\end{abstract}

Keywords: analysis, explanation text, newspaper, teaching materials.

\begin{abstract}
ABSTRAK
Penelitian ini dilakukan untuk memberikan solusi bagi permasalahan dalam pembelajaran, salah satunya kesulitan guru dalam memilih atau menentukan bahan ajar yang tepat bagi peserta didik. Selain itu kesulitan peserta didik untuk membedakan teks eksplanasi dengan teks lain turut menjadi permasalahan. Penelitian ini diharapkan mampu memberi solusi mengenai pemilihan bahan ajar yang bervariasi serta sesuai dengan pembelajaran teks eksplanasi di SMA. Tujuan dari penelitian ini yaitu untuk menganalisis struktur dan kaidah kebahasaan teks eksplanasi yang terdapat dalam surat kabar Pikiran Rakyat sebagai alternatif pemilihan bahan ajar teks eksplanasi di kelas XI SMA. Metode yang digunakan dalam penelitian ini yaitu kualitatif deskriptif. Sumber data yang digunakan dalam penelitian ini yaitu 10 teks eksplanasi yang berasal dari surat kabar Pikiran Rakyat. Data penelitian yang didapatkan berupa hasil analisis struktur dan kaidah kebahasaan teks eksplanasi sebagai berikut. Pertama, struktur teks eksplanasi di
\end{abstract}


antaranya judul, pernyataan umum, urutan proses terjadinya fenomena, dan penutup. Kedua, kaidah kebahasaan teks eksplanasi di antaranya konjungsi temporal dan konjungsi kausalitas. Ketiga, bahan ajar teks eksplanasi yang didasarkan pada hasil analisis yang telah dilakukan, dan dapat digunakan dalam pembelajaran materi teks eksplanasi di kelas XI SMA.

Kata kunci: analisis, teks eksplanasi, surat kabar, bahan ajar

\section{A. Pendahuluan}

Permasalahan yang sering terjadi dalam pembelajaran yang paling utama adalah kesulitan guru dalam memilih atau menentukan bahan ajar yang tepat bagi peserta didik. Prastowo (2012, hlm. 24) mengatakan bahwa, "Bahan ajar memiliki peran dalam proses pembelajaran, salah satunya membuat pembelajaran lebih efektif dan interaktif." Bahan ajar yang baik tentunya diharapkan bisa membantu untuk lebih memudahkan pencapaian dari tujuan pembelajaran.

Permasalahan tersebut salah satunya disebabkan oleh masih kurang tersedianya materi bahan ajar dalam kurikulum ataupun silabus, yang mana materi bahan ajar tersebut hanya dituliskan secara garis besar dalam bentuk "materi pokok". Selanjutnya, tugas guru adalah menjabarkan kembali materi pokok tersebut secara rinci hingga menjadi bahan ajar yang lengkap. Putra, dkk. (2014, hlm. 2) mengungkapkan hasil penelitiannya bahwa, "Kenyataan di lapangan belum semua guru mampu mengembangkan bahan ajar secara mandiri. Para pendidik selama ini mengandalkan buku paket yang telah tersedia ataupun Lembar Kerja Siswa (LKS) yang telah beredar di sekolahsekolah, tanpa memodifikasi terlebih dahulu." Pendapat tersebut diperkuat oleh Zuriah dkk (2016, 13 hlm.40) mengatakan, "Permasalahan yang muncul dalam persoalan bahan ajar adalah guru-guru di sekolah banyak yang "gagap" dan mengalami kesulitan ketika diminta untuk menyusun bahan ajar sendiri, dan lebih banyak yang menggunakan bahan ajar buatan orang lain ataupun bikinan pabrik pada kegiatan pembelajaran yang mereka lakukan." Sementara itu, guru termasuk salah satu faktor penting untuk mempengaruhi, serta menentukan keberhasilan pembelajaran peserta didik. Selain itu, guru juga dituntut untuk lebih kreatif, tidak hanya dalam penyusunan bahan ajar sendiri, 
melainkan juga dalam pemanfaatan lingkungan sekitar untuk digunakan sebagai sumber belajar.

Permasalahan lainnya bahwa kondisi pembelajaran peserta didik dapat dikatakan masih kurang maksimal terutama dalam menganalisis struktur dan kaidah kebahasaan teks eksplanasi. Selain itu, tidak sedikit peserta didik yang masih sulit membedakan teks eksplanasi dengan teks lainnya. Hal ini didasarkan pada hasil wawancara saya terhadap salah satu guru bahasa Indonesia di SMK Pst. Al- Huda yang mengatakan bahwa, "Peserta didik kurang antusias terhadap pembelajaran teks eksplanasi, serta beberapa peserta didik bahkan masih sulit untuk membedakan teks eksplanasi dengan teks lainnya." Hal ini tentu saja berdampak terhadap kesulitan peserta didik dalam menganalisis struktur dan kaidah kebahasaan teks eksplanasi. Pengetahuan me-mahami teks eksplanasi meliputi pengertian, struktur, serta kaidah-kaidah kebahasaannya.

Kesulitan peserta didik dalam membedakan isi teks ekplanasi dengan teks lain disebabkan karena memang teks eksplanasi bisa dikatakan sebagai teks yang rumit. Sebagaimana yang diungkapkan oleh Emilia (2011, hlm. 127) bahwa, "Teks eksplanasi dapat dikatakan lebih rumit dari pada teks-teks lain karena merupakan gabungan dari berbagai jenis teks seperti deskriptif, prosedur dan teks argumentasi, seperti eksposisi". Berdasarkan hal tersebut, bisa disimpulkan bahwa, dalam mempelajari teks eksplanasi membutuhkan penguasaan dan pemahaman yang lebih baik lagi bagi para pendidik maupun peserta didik karena teks eksplanasi merupakan materi yang rumit.

Selain itu, membaca termasuk salah satu keterampilan berbahasa yang kompleks dan harus dikuasai. Tarigan (2015, hlm. 11) mengatakan bahwa, "Membaca termasuk suatu keterampil-an yang kompleks, yang rumit, yang mencakup atau melibatkan serangkaian keterampilan-keterampilan yang lebih kecil, yaitu: pengenalan aksara serta tanda-tanda baca, korelasi aksara beserta tanda baca dengan unsurunsur linguistik yang formal, dan hubungan lanjut dari $A$ dan $B$ dengan makna atau meaning" Menganalisis struktur dan kaidah kebahasaan teks eksplanasi termasuk salah satu dari 
empat keterampilan berbahasa, yaitu membaca. Keterampilan membaca tentu sangat penting untuk dikuasai peserta didik.

Kesulitan peserta didik dalam menganalis tidak mengherankan, sebab membaca merupakan proses yang rumit. Sebagaimana yang dikemukakan oleh Sadhono dan Slamet (dalam Purnamasari, 2014, hlm. 12) bahwa, "Keterampilan membaca termasuk suatu keterampilan yang bertujuan mengenal dan memahami tulisan dalam bentuk urutan lambanglambang dan grafis dan perubahannya menjadi wicara bermakna dalam bentuk pemahaman diam-diam atau peng-ujaran keraskeras." Selain itu, Tarigan (2015, hlm. 9) mengatakan, "Tujuan utama dalam membaca yaitu untuk mencari serta memperoleh informasi, mencakup isi, memahami makna bacaan." Berdasarkan hal tersebut, jelaslah bahwa kegiatan membaca tidak bisa dianggap mudah. Sebab membaca tidak hanya mengujarkan kalimatkalimat yang terdapat dalam suatu bacaan, melainkan juga harus bisa memahami, menyimpulkan, dan memberikan makna.
Penelitian ini berfokus pada alanisis teks eksplanasi dari media cetak berupa surat kabar Pikiran Rakyat, serta penyusunan bahan ajar berdasarkan materi mengenai teks eksplanasi berupa struktur dan kaidah kebahasaannya. Berdasarkan permasalahan yang dipaparkan pada uraian-uraian tersebut, maka disusunlah sebuah penelitian yang berjudul "Analisis Struktur dan Kaidah Kebahasaan Teks Eksplanasi pada Surat Kabar Pikiran Rakyat sebagai Alternatif Bahan Ajar Kelas XI SMA"

\section{B. Metode Penelitian}

Pada penelitian ini, peneliti memilih penelitian dengan menggunakan metode yang bersifat kualitatif dan dilihat secara deskriptif analisis, yaitu metode yang digunakan dengan cara menganalisis dan menguraikan data untuk menggambar-kan keadaan objek yang diteliti menjadi pusat perhatian penelitian. Menurut Sugiyono (2017, hlm. 9), metode kualitatif adalah sebagai berikut.

"Metode kualitatif adalah
metode penelitian yang
berlandaskan pada filsafat
pospositivisme, digunakan
untuk meneliti pada kondisi
objek yang alamiah, (sebagai


lawannya

adalah

eksperimen) di mana peneliti adalah sebagai instrumen kunci, pengambilan sampel sumber data dilakukan secara purposive dan snowball, teknik pengumpulan dengan trianggulasi (gabungan), analisis data bersifat induktif/kualitatif, dan hasil penelitian kualitatif lebih menekankan makna daripada generalisasi."

Berdasarkan kutipan di atas dapat dijelaskan bahwa dalam penelitian kualitatif, haruslah pada kondisi objek dan situasi yang alamiah. Situasi alamiah ini berarti situasi yang apa adanya tanpa dimanipulasi ataupun diberikan treatment oleh peneliti. Selain itu, instrumen yang digunakan dalam penelitian kualitatif yaitu berupa orang atau peneliti itu sendiri.

Suryabrata (2015, hlm. 75) mengatakan bahwa, "Penelitian kualitatif memiliki beberapa metode, salah satunya metode deskriptif. Metode deskriptif merupakan metode yang menggambarkan ciri-ciri data secara akurat sesuai dengan sifat alamiah data itu sendiri." Artinya, tujuan penelitian deskriptif adalah untuk membuat perencanaan sistematis, faktual, dan akurat mengenai fakta dan sifat populasi daerah tertentu.

Metode deskriptif digunakan dalam meneliti keadaan sesuatu dan bertujuan untuk mendeskripsikan hal tersebut secara sistematis, faktual, dan akurat melalui fakta, sifat, dan hubungan antara fenomena yang diteliti. Sebagaimana menurut Aminuddin (2004, hlm. 16), "Metode deskriptif kualitatif artinya menganalisis bentuk deskripsi, tidak berupa angka atau koefisien tentang hubungan antarvariabel. Penelitian kualitatif melibatkan ontologi. Data yang dikumpulkan berupa kosakata, kalimat, dan gambar". Artinya, pada penelitian kualitatif, objek-objek yang dianalisis berupa kata-kata atau kalimat yang berbentuk deskripsi, serta tidak menganalisis mengenai angka-angka.

Berdasarkan penjelasan-penjelasan di atas, peneliti dapat mengetahui bahwa metode penelitian deskriptif merupakan metode kualitatif yang bertujuan untuk mengungkapkan berbagai informasi kualitatif dengan pendeskripsian yang teliti. Pada penelitian deskriptif hasil penelitian disajikan apa adanya tanpa diberikan 
kontrol oleh peneliti saat penelitian berlangsung. Jadi, dalam penelitian yang berjudul "Analisis Struktur dan Kaidah Kebahasaan Teks Eksplanasi pada Surat Kabar Pikiran Rakyat sebagai Alternatif Bahan Ajar Kelas XI SMA" digunakan metode penelitan yaitu kualitatif deskriptif.

Dalam melaksanakan kegiatan penelitian, perlu adanya teknik untuk mencapai hasil yang baik. Teknik pengumpulan data adalah cara yang digunakan untuk mengumpulan informasi atau fakta-fakta yang ada di lapangan. Berdasarkan jenis penelitian yang dipilih, penulis menggunakan teknik pengumpulan data berupa studi pustaka dan dokumentasi.

\section{C.Hasil Penelitian dan Pembahasan}

Penelitian ini menganalisis mengenai struktur dan kaidah kebahasaan Teks Eksplanasi pada surat kabar Pikiran Rakyat edisi 2021. Data yang disajikan merupakan hasil analisis dari 10 teks eksplanasi yang dipilih dari surat kabar Pikiran Rakyat edisi 2021. Adapun struktur dari teks eksplanasi di antaranya yaitu judul, pernyataan umum, urutan proses terjadinya fenomena, serta penutup atau simpulan. Selain itu, dibahas pula mengenai kaidah kebahasaan teks eksplanasi di antaranya konjungsi temporal dan konjungsi kausalitas. Setelah itu, hasil penelitian mengenai struktur dan kaidah kebahasaan akan dievaluasi kelayakannya untuk dimanfaatkan sebagai bahan ajar dengan bentuk handout. Bahan ajar tersebut ditujukan untuk pembelajaran peserta didik kelas XI.

Adapun analisis ini terdiri dari 10 teks eksplanasi dengan hasil sebagai berikut.

1. Teks Eksplanasi 1: Jumlah ODGJ naik akibat Pandemi \& Faktor Ekonomi

Berdasarkan temuan peneliti dalan teks eksplanasi tersebut, dapat disimpulkan bahwa teks eksplanasi yang berjudul "Jumlah ODGJ Naik Akibat Pandemi \& Faktor Ekonomi" tersebut telah memuat secara lengkap setiap indikator dari struktur dan kaidah kebahasaan teks eksplanasi. Adapun indikator-indikator tersebut di antaranya adalah sebagai berikut. Judul merupakan struktur pertama di dalam teks eksplanasi. Pada teks tersebut judul yang digunakan adalah "Jumlah ODGJ Naik Akibat Pandemi \& Faktor Ekonomi." Selanjutnya, pada teks tersebut memuat pernyataan umum yang menjelaskan gambaran mengenai peristiwa yang terjadi. 
Pernyataan umum yang terdapat dalam teks tersebut berupa perincian mengenai peningkatan jumlah ODGJ serta persentase penderita ODGJ tersebut berdasarkan umur, jenis kelamin, dan sebagainya. Setelah pembahasan mengenai pernyataan umum, indikator selanjutnya yaitu urutan proses terjadinya fenomena. Pada teks tersebut, urutan proses terjadinya fenomena ditandai dengan penjelasan mengenai penyebab terjadinya fenomena tersebut, yaitu faktor ekonomi. Selain faktor ekonomi, ada juga penyebab lainnya seperti faktor genetik, faktor lingkungan, serta pemakaian obat-obatan. Bagian penutup dalam teks eksplanasi tersebut berupa tindakan penanganan kesehatan jiwa secara meluruh di Kota Cimahi serta pelatihan tenaga dokter dan pemanfaatan obat-obatan. Kaidah kebahasaan dalam teks eksplanasi tersebut mencakup konjungsi temporal dan konjungsi kausalitas. Adapun konjungsi temporal yang digunakan yaitu kemudian. Sementara untuk konjungsi kausalitasnya berupa karena.

2. Teks Eksplanasi 2: Lahan Kritis Meluas Banjir Terjang Kertasari

Berdasarkan temuan peneliti dalan teks eksplanasi tersebut, dapat disimpulkan bahwa teks eksplanasi yang berjudul "Lahan Kritis Meluas Banjir Terjang Kertasari” tersebut memuat beberapa indikator dari struktur dan kaidah kebahasaan teks eksplanasi. Adapun indikator-indikator tersebut di antaranya adalah sebagai berikut. Judul merupakan struktur pertama di dalam teks eksplanasi. Pada teks tersebut judul yang digunakan adalah "Lahan Kritis Meluas Banjir Terjang Kertasari." Selanjutnya, pada teks tersebut memuat pernyataan umum yang menjelaskan gambaran mengenai peristiwa yang terjadi. Pernyataan umum yang terdapat dalam teks tersebut berupa perincian mengenai keadaan di desa tersebut setelah terjadinya banjir bandang. Setelah pembahasan mengenai pernyataan umum, indikator selanjutnya yaitu urutan proses terjadinya fenomena. Pada teks tersebut, urutan proses terjadinya fenomena ditandai dengan penjelasan mengenai penyebab terjadinya fenomena tersebut. Penyebabnya adalah akibat makin meluasnya lahar kritis di daerah Kertasari. Bagian penutup dalam teks eksplanasi tersebut menjelaskan kebutuhan-kebutuhan warga yang terdampak serta menjelaskan bahwa 
beberapa warga terpaksa mengungsi ke rumah kerabatnya. Kaidah kebahasaaan dalam teks eksplanasi tersebut memuat konjungsi temporal berupa kata hingga dan saat. Sementara itu, tidak ditemukan konjungsi kausalitas dalam teks tersebut. Namun, dalam paragraf teks eksplanasi tersebut tetap memuat kalimat-kalimat kausalitas. Seperti salah satu contoh kalimat berikut ini.

Pasalnya, saat ini banyak warga terdampak banjir bandang yang terpaksa mengungsi ke rumah kerabatnya akibat rumah mereka belum bisa dihuni akibat endapan lumpur yang terbawa banjir bandang

3. Teks Eksplanasi 3: Terus Meningkat Pernikahan Dini Selama Pandemi

Berdasarkan temuan peneliti dalan teks eksplanasi tersebut, dapat disimpulkan bahwa teks eksplanasi yang berjudul "Terus Meningkat Pernikahan Dini Selama Pandemi" tersebut telah memuat secara lengkap setiap indikator dari struktur dan kaidah kebahasaan teks eksplanasi. Adapun indikator-indikator tersebut di antaranya adalah sebagai berikut. Judul merupakan struktur pertama di dalam teks eksplanasi. Pada teks tersebut judul yang digunakan adalah
"Terus Meningkat Pernikahan Dini Selama Pandemi." Selanjutnya, pada teks tersebut memuat pernyataan umum yang menjelaskan gambaran mengenai peristiwa yang terjadi. Pernyataan umum yang terdapat dalam teks tersebut berupa perincian mengenai data-data peningkatan fenomena pernikahan dini dari tahun 2019-2021. Setelah pembahasan mengenai pernyataan umum, indikator selanjutnya yaitu urutan proses terjadinya fenomena. Pada teks tersebut, urutan proses terjadinya fenomena ditandai dengan penjelasan mengenai penyebab terjadinya fenomena tersebut. Penyebabnya adalah akibat orang tua yang sudah tidak ingin lagi merawat anak, kekerasan seksual, faktor pandemi dan ekonomi. Adapun indikator mengenai kaidah kebahasaan teks eksplanasi, dimuat secara lengkap dalam teks tersebut. Di antaranya konjungsi temporal yaitu lalu, sejak, hingga, saat dan akhirnya. Selain itu, konjungsi kausalitas berupa oleh karena itu, karena dan sehingga.

4. Teks Eksplanasi 4: Papan Reklame dan Pohon Roboh Berdasarkan temuan peneliti dalan teks eksplanasi tersebut, dapat disimpulkan bahwa teks eksplanasi 
yang berjudul "Papan Reklame dan Pohon Roboh" tersebut telah memuat secara lengkap setiap indikator dari struktur dan kaidah kebahasaan teks eksplanasi. Adapun indikator-indikator tersebut di antaranya adalah sebagai berikut. Judul merupakan struktur pertama di dalam teks eksplanasi. Pada teks tersebut judul yang digunakan adalah "Papan Reklame dan Pohon Roboh." Selanjutnya, pada teks tersebut memuat pernyataan umum yang menjelaskan gambaran mengenai peristiwa yang terjadi. Pernyataan umum yang terdapat dalam teks tersebut berupa perincian mengenai data lokasi serta akibat yang ditimbulkan dari peristiwa tersebut. Setelah pembahasan mengenai pernyataan umum, indikator selanjutnya yaitu urutan proses terjadinya fenomena. Pada teks tersebut, urutan proses terjadinya fenomena ditandai dengan penjelasan mengenai penyebab terjadinya fenomena tersebut. Penyebabnya adalah akibat hujan deras yang disertai dengan angin kencang. Bagian penutup dalam teks tersebut yaitu menjelaskan adanya penanganan yang segera dilakukan oleh tim gabungan Pemkot Cimahi terhadap peristiwa tersebut. Adapun indikator

mengenai

kaidah

kebahasaan teks eksplanasi, dimuat secara lengkap dalam teks tersebut. Di antaranya konjungsi temporal yaitu kata hingga. Selain itu, konjungsi kausalitas berupa karena dan sehingga.

5. Teks Eksplanasi 5: Lima Rumah Rusak Dipicu Cuaca \& Pertambangan

Berdasarkan temuan peneliti dalan teks eksplanasi tersebut, dapat disimpulkan bahwa teks eksplanasi yang berjudul "Lima Rumah Rusak Dipicu Cuaca \& Pertambangan" tersebut telah memuat secara lengkap setiap indikator dari struktur dan kaidah kebahasaan teks eksplanasi. Adapun indikator-indikator tersebut di antaranya adalah sebagai berikut. Judul merupakan struktur pertama di dalam teks eksplanasi. Pada teks tersebut judul yang digunakan adalah "Lima Rumah Rusak Dipicu Cuaca \& Pertambangan". Selanjutnya, pada teks tersebut memuat pernyataan umum yang menjelaskan gambaran mengenai peristiwa yang terjadi. Pernyataan umum yang terdapat dalam teks tersebut berupa keadaan tanah di lokasi kejadian, serta laporan mengeni kerusakan-kerusakan yang ditimbulkan oleh kejadian tersebut. 
Setelah pembahasan mengenai pernyataan umum, indikator selanjutnya yaitu urutan proses terjadinya fenomena. Pada teks tersebut, urutan proses terjadinya fenomena ditandai dengan penjelasan mengenai penyebab terjadinya fenomena tersebut, yaitu curah hujan yang tinggi, kestabilan lereng yang rendah, serta adanya aktivitas blasting di area tersebut. Bagian penutup dalam teks eksplanasi tersebut menjelaskan tindakan yang diambil untuk mengantisipasi kejadian longsor berikutnya. Kaidah kebahasaan dalam teks eksplanasi tersebut mencakup konjungsi temporal dan konjungsi kausalitas.

6. Teks Eksplanasi 6: Sejumlah Rumah Terancam Longsor

Berdasarkan temuan peneliti dalan teks eksplanasi tersebut, dapat disimpulkan bahwa teks eksplanasi yang berjudul "Sejumlah Rumah Terancam Longsor" tersebut telah memuat secara lengkap setiap indikator dari struktur dan kaidah kebahasaan teks eksplanasi. Adapun indikator-indikator tersebut di antaranya adalah sebagai berikut. Judul merupakan struktur pertama di dalam teks eksplanasi. Pada teks tersebut judul yang digunakan adalah
"Sejumlah Rumah Terancam Longsor." Selanjutnya, pada teks tersebut memuat pernyataan umum yang menjelaskan gambaran mengenai peristiwa yang terjadi. Pernyataan umum yang terdapat dalam teks tersebut berupa perincian mengenai data lokasi kejadian serta rincian mengenai tebing yang ambruk. Setelah pembahasan mengenai pernyataan umum, indikator selanjutnya yaitu urutan proses terjadinya fenomena. Pada teks tersebut, urutan proses terjadinya fenomena ditandai dengan penjelasan dari beberapa narasumber mengenai penyebab terjadinya fenomena tersebut. Pada awalnya hujan deras mengguyur daerah Cisayong. Selain itu keadaan tanah yang labil juga turun mejadi penyebabnya. Pada akhirnya, di suatu pagi seseorang mendengar suara gemuruh dan terjadilah tebing ambruk. Pada bagian penutup dijelaskan beberapa simpulan mengenai teks tersebut, seperti kerugian-kerugian yang disebabkan peristiwa tersebut serta penanggulangan yang dilakukan secara bergotong royong. Adapun indikator mengenai kaidah kebahasaan teks eksplanasi, dimuat secara lengkap dalam teks tersebut. 
Di antaranya konjungsi temporal yaitu kata saat, sebelumnya, dan sejak.. Selain itu, konjungsi kausalitas berupa karena dan agar.

\section{Teks Eksplanasi 7: Warga Cigeblig Sulit Dapat Air Bersih}

Berdasarkan temuan peneliti dalan teks eksplanasi tersebut, dapat disimpulkan bahwa teks eksplanasi yang berjudul "Warga Cigeblig Sulit Dapat Air Bersih" tersebut telah memuat secara lengkap setiap indikator dari struktur dan kaidah kebahasaan teks eksplanasi. Adapun indikator-indikator tersebut di antaranya adalah sebagai berikut. Judul merupakan struktur pertama di dalam teks eksplanasi. Pada teks tersebut judul yang digunakan adalah "Warga Cigeblig Sulit Dapat Air Bersih" Selanjutnya, pada teks tersebut memuat pernyataan umum yang menjelaskan gambaran mengenai peristiwa yang terjadi. Pernyataan umum yang terdapat dalam teks tersebut berupa perincian mengenai data lokasi yang mengalami kejadian kesulitan air bersih. Pada pernyataan umum tersebut juga dijelaskan bahwa warga mengandalkan air dari ketua RW serta menggunakan air galon dan air sawah untuk memenuhi kebutuhan air di daerah tersebut. Setelah pembahasan mengenai pernyataan umum, indikator selanjutnya yaitu urutan proses terjadinya fenomena. Pada teks tersebut, urutan proses terjadinya fenomena ditandai dengan penyebab terjadinya fenomena tersebut. Adapun penyebabnya adalah dikarenakan mata air yang berada di daerah tersebut tertutup oleh proyek kereta cepat. Pada bagian penutup dijelaskan kesimpulan dari teks eksplanasi tersebut. Adapun kesimpulannya menyatakan bahwa warga memang menggunakan air sawah dan membeli air galon isi ulang untuk memenuhi kebutuhan air. Selain itu beberapa warga juga ada yang memasang pipa/selang sendiri selain mengandalkan air yang dibagikan oleh ketua RT. Sementara itu, untuk mengatasi masalah tersebut, salah satu pihak kereta cepat akan berkoordinasi terlebih dahulu dengan tim lapangan. Adapun indikator mengenai kaidah kebahasaan teks eksplanasi, dimuat secara lengkap dalam teks tersebut. Di antaranya konjungsi temporal yaitu kata akhirnya, demi, dan saat.. Selain itu, konjungsi kausalitas berupa karena dan meski demikian. 
8. Teks Eksplanasi 8: Sawah Mengering Tiga Tahun Air Tak Mengalir

Berdasarkan temuan peneliti dalan teks eksplanasi tersebut, dapat disimpulkan bahwa teks eksplanasi yang berjudul "Sawah Mengering Tiga Tahun Air Tak Mengalir" tersebut telah memuat secara lengkap setiap indikator dari struktur dan kaidah kebahasaan teks eksplanasi. Adapun indikator-indikator tersebut di antaranya adalah sebagai berikut. Judul merupakan struktur pertama di dalam teks eksplanasi. Pada teks tersebut judul yang digunakan adalah "Sawah Mengering Tiga Tahun Air Tak Mengalir". Selanjutnya, pada teks tersebut memuat pernyataan umum yang menjelaskan gambaran mengenai peristiwa yang terjadi. Pernyataan umum yang terdapat dalam teks tersebut berupa perincian mengenai data lokasi serta keadaan sawah yang mengalami kekeringan tersebut. Pada pernyataan umum tersebut juga dijelaskan bahwa sawah tersebut pada akhirnya terpaksa ditanami jagung, pohon sawo atau pun pohon yang lainnya. Setelah pembahasan mengenai pernyataan umum, indikator selanjutnya yaitu urutan proses terjadinya fenomena.
Pada teks tersebut, urutan proses terjadinya fenomena ditandai dengan penyebab terjadinya fenomena tersebut. Adapun penyebabnya adalah dikarenakan debit air kecil dan air bocor dari saluran. Selain itu, penyebab lainnya adalah tidak adanya pengatur air yang ditunjuk oleh pemerintah desa. Pada bagian penutup dijelaskan kesimpulan dari teks eksplanasi tersebut. Adapun kesimpulannya menyatakan bahwa dikarenakan belum ada tindakan apapun dari pemerintah, warga terpaksa harus membeli beras, serta pada akhirnya sebagian sawah di daerah tersebut dijual untuk dijadikan pemukiman ataupun kandang ternak. Adapun indikator mengenai kaidah kebahasaan teks eksplanasi, dimuat secara lengkap dalam teks tersebut. Di antaranya konjungsi temporal yaitu kata hingga dan saat.. Selain itu, konjungsi kausalitas berupa kata kalau.

9. Teks Eksplanasi 9: Pasar Ciawi Terbakar Puluhan Kios Ludes Berdasarkan temuan peneliti dalan teks eksplanasi tersebut, dapat disimpulkan bahwa teks eksplanasi yang berjudul "Pasar Ciawi Terbakar Puluhan Kios Ludes" tersebut telah memuat secara lengkap setiap 
indikator dari struktur dan kaidah kebahasaan teks eksplanasi. Adapun indikator-indikator tersebut di antaranya adalah sebagai berikut. Judul merupakan struktur pertama di dalam teks eksplanasi. Pada teks tersebut judul yang digunakan adalah "Pasar Ciawi Terbakar Puluhan Kios Ludes". Selanjutnya, pada teks tersebut memuat pernyataan umum yang menjelaskan gambaran mengenai peristiwa yang terjadi. Pernyataan umum yang terdapat dalam teks tersebut berupa perincian mengenai data lokasi serta kondisi dan waktu kejadian kebakaran. Setelah pembahasan mengenai pernyataan umum, indikator selanjutnya yaitu urutan proses terjadinya fenomena. Adapun penyebabnya dikarenakan hubungan pendek arus listrik yang percikan apinya mengenai atap kios dan merembet ke seluruh kios. Pada bagian penutup dijelaskan terkait jumlah kios yang terbakar, serta keadaan api yang sulit dipadamkan hingga berjam-jam. Selain itu disimpulkan pula penyebab terjadinya kebakaran tersebut, meskipun belum ada keterangan resmi. Adapun indikator mengenai kaidah kebahasaan teks eksplanasi, dimuat secara lengkap dalam teks tersebut. Di antaranya konjungsi temporal yaitu kata hingga dan kemudian.. Selain itu, konjungsi kausalitas berupa kata sebab.

10. Teks Eksplanasi 10: Berjamur, Harga Jual Tembakau Turun Berdasarkan temuan peneliti dalan teks eksplanasi tersebut, dapat disimpulkan bahwa teks eksplanasi yang berjudul "Berjamur, Harga Jual Tembakau Turun" tersebut telah memuat secara lengkap setiap indikator dari struktur dan kaidah kebahasaan teks eksplanasi. Adapun indikator-indikator tersebut di antaranya adalah sebagai berikut. Judul merupakan struktur pertama di dalam teks eksplanasi. Pada teks tersebut judul yang digunakan adalah "Berjamur, Harga Jual Tembakau Turun". Selanjutnya, pada teks tersebut memuat pernyataan umum yang menjelaskan gambaran mengenai peristiwa yang terjadi. Pernyataan umum yang terdapat dalam teks tersebut berupa perincian mengenai data lokasi serta mengejelaskan terjadinya fenomena hasil panen tembakau dengan kualitas rendah yang menyebabkan turunnya harga jual. Setelah pembahasan mengenai pernyataan umum, 
indikator selanjutnya yaitu urutan proses terjadinya fenomena. Adapun penyebab turunnya harga tembakau dikarenakan oleh kualitas tembakau yang dihasilkan rendah. Sehingga harga tembakau tersebut turun menjadi Rp 30.000 per kilogram. Selain itu, penyebab rendahnya harga tembakau tersebut juga diakibatkan oleh bandar yang belum datang ke petani. Selain kedua hal tersebut, harga tembakau menjadi rendah akibat daun tembakau yang masih kecil hingga yang sudah besar dan lebat, terguyur air hujan. Pada bagian penutup dijelaskan kesimpulan dari fenomena yang terjadi. Adapun kesimpulannya adalah bahwa penurunan kualitas tembakau tersebut dikonfirmasi oleh Kepala Dinas Pertanian Kabupaten Majalengka. Namun, beliau mengakatakan bahwa penurunan kualitas tembakau tersebut hanya terjadi di beberapa wilayah saja. Adapun indikator mengenai kaidah kebahasaan teks eksplanasi, dimuat secara lengkap dalam teks tersebut. Di antaranya konjungsi temporal yaitu kata saat dan ketika.. Selain itu, konjungsi kausalitas berupa karena dan maka.

\section{Kesimpulan}

Penelitian ini bertujuan untuk mengetahui hasil analisis struktur dan kaidah kebahasaan teks eksplanasi pada surat kabar Pikiran Rakyat sebagai bahan ajar kelas XI SMA. Berdasarkan penelitian yang telah dilakukan, maka kesimpulan yang didapatkan adalah sebagai berikut.

1. Berdasarkan penelitian yang telah dilakukan, didapatkan data bahwa 10 teks eksplanasi yang telah dianalisis, memuat secara lengkap struktur dari teks eksplanasi. Di antaranya judul, pernyataan umum, urutan proses terjadinya fenomena, serta penutup.

2. Berdasarkan penelitian yang telah dilakukan, didaparkan data bahwa teks eksplanasi yang telah dianalisis, memuat secara lengkap kaidah kebahasaan teks eksplanasi. Di antaranya yaitu konjungsi temporal dan konjungsi kausalitas.

Berdasarkan penelitian yang telah dilakukan, 10 teks eksplanasi yang dianalisis, dapat dimanfaatkan sebagai alternatif pemilihan bahan ajar di kelas XI SMA. Alasannya, karena teks tersebut telah sesuai dan juga relevan dengan tuntutan kurikulum $2013 \quad$ khususnya 
pembelajaran teks eksplanasi yang terdapat pada materi kelas XI SMA.

\section{DAFTAR PUSTAKA}

Alwi, dkk. (2003). Tata bahasa baku bahasa Indonesia. Jakarta: Balai Pustaka.

Arikunto, S. 2013. Prosedur penelitian suatu pendekatan praktik. Jakarta: PT. Rineka Cipta.

Djuroto, T. (2002). Manajemen penerbitan pers. Bandung: PT. Remaja Rosdakarya.

HM, Zaenuddin. (2017). The Journalist. Jakarta: Campustaka.

Ismawati, E. (2011). Metode penelitian pendidikan bahasa \& sastra. Surakarta: Yuma Pressindo.

Kementerian Pendidikan dan Kebudayaan. (2017). Buku siswa Bahasa Indonesia untuk SMA/MA/SMK/MAK kelas XI. Jakarta: Kementerian Pendidikan dan Kebudayaan.

Kisworo, M.W., Iwan Sofana. (2017). Menulis karya ilmiah. Bandung: Informatika Bandung.

Kosasih, E. (2017). Jenis-jenis teks. Bandung: Yrama Widya.

Kosasih, E. (2021). Pengembangan bahan ajar. Jakarta: Bumi Aksara.

Muhtadi, AS. (2018). Pengantar ilmu jurnalistik. Bandung: Sembiosa Rekatama Media.

Mulyadi, dkk. (2018). Bahasa Indonesia untuk siswa SMAMA/SMK-MAK kelas XI.
Bandung: Penerbit Yrama Widya.

Mulyasa. (2013). Pengembangan dan implementasi kurikulum 2013. Bandung: PT. Remaja Rosdakarya.

Prastowo, A. (2012). Panduan kreatif membuat bahan ajar inovatif. Yogyakarta: Diva Press.

Restuti, dkk. (2017). Mandiri Bahasa Indonesia. Jakarta: Erlangga.

Romli, K. (2016). Komunikasi massa. Jakarta: Grasindo.

Subana, H.M.. (2009). Dasar-dasar penelitian ilmiah. Bandung: Pustaka Setia.

Sugiyono. (2017). Metode penelitian kuantitatif, kualitatif, dan $R \& D$. Bandung: Alfabeta CV.

Sugiyono. (2018). Metode penelitian pendidikan (pendekatan kuantitatif, kualitatif, dan R\&D). Bandung: Alfabeta.

Sumadiria, AS.H. (2005). Jurnalistik Indonesia: menulis berita dan feature. Bandung: PT. Remaja Rosdakarya.

Suryabrata, S. (2012). Metodologi penelitian. Jakarta: PT. Grafindo Persada.

Sutopo. (2006). Metodologi penelitian kualitatif. Surakarta: UNS.

Tarigan, HG. (2015). Membaca: sebagai suatu keterampilan berbahasa. Bandung: CV Angkasa.

Wijayanti, SH, dkk. (2019). Bahasa Indonesia: penulisan dan penyajian karya ilmiah. Depok: PT. Raja Grafindo Persada. 